\title{
THE INFLUENCE OF PRODUCT QUALITY, PERCEIVED VALUE, PRICE FAIRNESS, EWOM, AND SATISFACTION TOWARDS REPURCHASE INTENTION AT XING FU TANG
}

\author{
Rendika Nugraha ${ }^{1}$, Lhoekspardi Dharmawan Wiguna ${ }^{2}$ \\ 1,2 President University, Bekasi, Indonesia \\ Correspondence email: ${ }^{1}$ rendika@president.ac.id
}

\begin{abstract}
The purpose of this study is to find out the influence of product quality, perceived value, price fairness, Electronic Word of Mouth (EWOM) and satisfaction towards repurchase intention at Xing Fu Tang. This study uses quantitative method with 7-point Likert-scale with 1 represent strongly disagree and 7 represent strongly agree. Questionnaires were spread online and collected 303 sample size using purposive sampling method. The respondents are people who had tasted Xing Fu Tang and lived in Greater Jakarta, Indonesia. The findings indicate that product quality, perceived value, price fairness, and EWOM positively influence satisfaction and satisfaction positively influence repurchase intention, while EWOM does not influence repurchase intention. This study's dimensions are adapted from various previous study and come from various countries and industries to create new finding in food beverage industry mainly bubble drink seller especially Xing Fu Tang. The findings suggest that Xing Fu Tang pay more attention to the product quality.
\end{abstract}

Keywords: electronic word of mouth; perceived value; price fairness; product quality; repurchase intention

\section{ABSTRAK}

Tujuan dari penelitian ini adalah untuk mengetahui pengaruh kualitas produk, nilai yang dirasakan, kewajaran harga, Electronic Word of Mouth (EWOM) dan kepuasan terhadap niat beli ulang pada Xing Fu Tang. Penelitian ini menggunakan metode kuantitatif dengan skala Likert 7 poin dengan 1 mewakili sangat tidak setuju dan 7 mewakili sangat setuju. Kuesioner disebarkan secara online dan dikumpulkan sebanyak 303 sampel dengan metode purposive sampling. Respondennya adalah orang-orang yang pernah mencicipi Xing Fu Tang dan tinggal di Jabodetabek, Indonesia. Hasil penelitian menunjukkan bahwa kualitas produk, nilai yang dirasakan, kewajaran harga, dan EWOM berpengaruh positif terhadap kepuasan dan kepuasan secara positif mempengaruhi niat pembelian ulang, sedangkan EWOM tidak mempengaruhi niat pembelian ulang. Dimensi penelitian ini diadaptasi dari berbagai penelitian sebelumnya dan berasal dari berbagai negara dan industri untuk menciptakan temuan baru dalam industri makanan minuman terutama penjual bubble drink khususnya Xing Fu Tang. Temuan menunjukkan bahwa Xing Fu Tang lebih memperhatikan kualitas produk.

Kata kunci: electronic word of mouth; kewajaran harga; kualitas produk; niat membeli kembali; perceived value

ARTICLE INFORMATION

Article History: submitted: March 24, 2021; revised: June 14, 2021; accepted: June 28, 2021

JEL Classification: M31

How to Cite: Nugraha, R., Wiguna, L. D. (2021). The Influence of Product Quality, Perceived Value, Price Fairness, EWOM, and Satisfaction Towards Repurchase Intention at Xing Fu Tang. JIMFE (Jurnal IImiah Manajemen Fakultas Ekonomi), 7(1), 89-98. https://doi.org/10.34203/jimfe.v7i1.3156

\section{INTRODUCTION}

Food and beverage industry growth marked as one of the industry which has the biggest growth. One of the phenomenon that occurs in Indonesia is the fantastic growth of Boba. Boba is a variation of sweet 
Rendika Nugraha: The Influence of ...

drink topping which made from tapioca flour. It is famous to be combined with tea and known as Bubble tea. The tremendous growth of the demand of bubble tea in Indonesia reach 8,5 percent from January 2018 until December 2018. This number is the biggest number in the South East Asia, followed by Filipina 3,5 percent and Thailand 3 percent (Astutik, 2019). Based on Grab Big Data the average consumption of Boba ordered via Grab by Indonesian up to three cups per person in a month (Grab, 2019).

The product in this research is boba drink product from Xing Fu Tang. Xing Fu Tang is a Taiwanese which franchise founded in January 2018 has more than sixty Xing Fu Tang outlets spread in Taiwan and cities such as Manila, Hong Kong, Vancouver, and Shenzhen (Karen \& Lau, 2019). In Indonesia, it first opened in Lippo Mall Puri, West Jakarta on June 2019. Followed by Kemang Village Mall, Pluit Village, and begin to spread to other big city (Rakyat Merdeka News, 2019). It is famous and at the time they opened their second store, it has non-stop queuing and has to be guarded by security (KumparanFOOD, 2019). Despite the famous brand, Xing Fu Tang only have 17 franchise store all around Indonesia and only opened in big cities.

One of the biggest competitors of Xing Fu Tang is Kokumi. Kokumi started in 2018 and is local brand which $70 \%$ of the ingredients comes from Indonesia. Kokumi price ranging from Rp18.000Rp35.000. According to Jacqueline Karina, Chief Executive Officet (CEO) and Founder of Kokumi stated that one outlet of Kokumi could sell 1.000-3.000 cups of boba per day. The growth of Kokumi is very high up to $1,000 \%$ and has already opened 30 outlets around Indonesia (Lidyana, 2019b). Xing fu tang is considered more famous than Kokumi based on the Instagram situation such as numbers of followers and engagement per post between these two brands as per June 2021. In addition, Xing Fu Tang fame caused tremendous que when they opened their second outlet (Mustinda, 2019). Customer need to que for one to two hours just to complete their orders especially in their first three branches. This case shown huge amount of orders at Xing Fu Tang, but in the other hand if customers have to spend hours to buy the beverage will they re-purchase beverage from Xing Fu Tang again? The tremendous growth of Boba will reach its optimum point, and when that condition continuing to occur, natural selection is not avoided. Based on Ahmad Heri, Economic and Business Observer, the retailer must have their own uniqueness to get awareness from the buyers (Lidyana, 2019a). The risk of losing the competition could become bigger since there are many brands offering the same products. Xing Fu Tang must find the right key to successfully lead the fierce competition (Ismail, 2020).

Based on Balasubramanian et al. (2018), that is critical to assure consumer satisfaction level remain high in order to generate repeat purchase. They studied the dimensions that play major role in affecting customers' decision to repurchase boba drink in Malaysia. Even though understanding on repurchase intention is important, in the Malaysian context, there have been limited research. Therefore, this study aiming to explore customer repurchase intention by analysing the relationship between EWOM, product quality, perceived value, and price fairness in relation to customer satisfaction at Xing Fu Tang.

\section{LITERATURE REVIEW AND HYPOTHESIS DEVELOPMENT Product Quality and Satisfaction}

Study by Han \& Hyun (2017) regarding impact of quality of hotel-restaurant image and physicalenvironment, food on satisfaction, service, and intention shows that in hospitality industry, customer satisfaction is significantly associated with the quality valuation on various goods performances. Previous research by Konuk (2019) discussing about WOM and revisit intention in restaurant suggest that customer satisfaction is in correlation with product quality. In addition, study by et al. (2019) in Turkey regarding electrical appliance industry indicates that quality connected to satisfaction with specific transaction exchanges. 


\section{$H_{1}$ : product quality positively influence satisfaction}

\section{Perceived Value and Satisfaction}

Previous study by Balasubramanian et al. (2018) in bubble drink industry in Malaysia indicates that there is relationship between perceived value and customer satisfaction. Konuk (2019) research highlight the positive influence on perceived value and customer satisfaction in context of restaurants. In addition, research in Malaysia upscale restaurant suggest that perceived value positively in correlation with customer satisfaction (Nazri et al. 2016).

\section{$H_{2}$ : perceived value positively influence satisfaction}

\section{Price Fairness and Satisfaction}

Study about tourist accommodation by Ali et al. (2018) suggest that satisfaction is affected by perception of price fairness and produce customer behavioral intention. Study in restaurant repatronage intention argued that customer satisfaction with organic food has a significant positive influence from price fairness (Abdullah et al., 2018). In addition, research by Konuk (2018) shows that satisfaction is positively affected by price fairness.

$H_{3}$ : price fairness positively influence satisfaction

\section{EWOM and Satisfaction}

According to study conducted by Farhat et al. (2019) regarding consumer online purchase intention indicate that EWOM is influencing attitude and customer satisfaction. Moreover, study from Kuo et al. (2013) in repeat purchase intention of female online shoppers investigate that customer satisfaction can be raised by positive WOM. Research by Setiawan et al. (2014) in tourism industry which discussing about customer loyalty in Bali shows that EWOM influence customer satisfaction significantly.

\section{$\mathrm{H}_{4}$ : EWOM positively influence satisfaction}

\section{EWOM and Repurchase Intention}

Prior study by Matute, et al. (2016) classify the characteristic of EWOM that influence the online repurchase intention with the roles of perceived usefulness and trust. In addition, Mao \& Lyu (2017) which study regarding repurchase intention in Airbnb shows that repurchase intention and EWOM has positive correlation. Moreover, Liang et al. (2017) has research regarding the repurchase intention in Airbnb using electronic word-of-mouth, price sensitivity, perceived authenticity as the variables that investigate repurchase intention and EWOM have positive correlation.

\section{$\mathrm{H}_{5}$ : EWOM positively influence repurchase intention}

\section{Satisfaction and Repurchase Intention}

Previous research by Balasubramanian, et al. (2018) in bubble drink industry in Malaysia argues that the most crucial factor in affecting customer behavior to repurchase intention is satisfaction. Research by Ismoyo et al. (2017) investigate that customer experience in the previous product purchasing is affecting customer repurchasing decision. Consumer will be satisfied if the consumer perceives the products actual performance better than or equal to their expectation. In addition, to increase the repurchase intention, customer satisfaction has an important role. In addition, research by Vijay et al. (2017) about role of web atmospherics and shopping values in repurchase intention and e-satisfaction in Mumbai, India, indicates that online satisfaction positively affect customer online repurchase intention. 


\section{H6: Satisfaction positively influence repurchase intention}

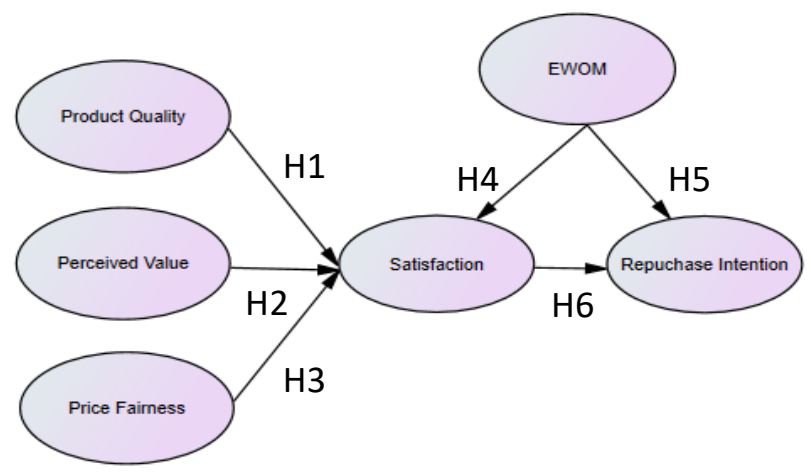

Figure 1. Framework

\section{RESEARCH METHOD}

Method in this study is quantitative method as the aim of this study to measure the correlation between factors. Questionnaires are made using Google Form and spread online. Respondents in this study were selected using purposive sampling to reach the aim of the study. In order to realize that, this research has specific criteria for the Respondents. First, People who comes from Greater Jakarta area since Xing fu tang has most branch in greater Jakarta area compare to another area in Indonesia. Second, They have ever consumed bubble drink, such as: Kokumi, Chatime, Tiger Sugar, Xi Boba, Diagon Alley, Hop Hop. Third, They have ever consumes Xing Fu Tang beverage at least once. A total of 303 valid respondents collected and being analyzed using structural equation modeling (SEM).

The questionnaire was divided into cover letter, screening questions, respondents profile, and item statements. The item statements in this study were adapted and adjusted from previous studies (Anggraeni \& Luthfi, 2018; Araci et al., 2017; Balasubramanian et al., 2018; Gök et al., 2019; Konuk, 2018, 2019; Mao \& Lyu, 2017; Ryu \& Lee, 2016). In measuring EWOM the questionnaire is being derived from Mao \& Lyu (2017) and Anggraeni \& Luthfi (2018) with four item statements. Three item statements is being the measurements for product quality and being adopted from Han \& Hyun (2017). Perceived value measurement is being derived from Konuk (2019) with three item statements. Measurement for price fairness is being adopted from Konuk (2018) with three items statements. To measure satisfaction, the questionnaire is being adopted from Balasubramanian et al. (2018) and Araci et. al. (2017) with four item statements. Last but not least, the questionnaire for repurchase intention being derived from Balasubramanian et al. (2018) and Araci et. al. (2017) with four item statements. 7-point Likert-scale is being used ranging from 1 (strongly disagree) to 7 (strongly agree).

\section{RESULT AND DISCUSSIONS Validity and Reliability}

Validity and reliability were being tested from total of 21 item statements. Validity test being tested using dimension reduction. To be considered valid the Kaiser-Meyer-Olkin (KMO) test must be greater than 0,6 and Bartletts test of Sphericity value must be relevant at $\alpha$ less than 0,05, communalities greater than 0,5 , total variance explained minimum 60 percent, and rotated component matrix greater than 0,4 (Chan \& Idris, 2017). The KMO value for independent and dependent variables are both valid as the value are 0.891 and 0,932 respectively. In addition, both value for Bartlett's test of shpericity are 0,000 . Test for total variance explained is considered valid as the value of independent and dependent variables are 68,781 and 71,872 respectively. The value of communalities and rotated component 
matrix will be shown as on Table 1. Reliability test being measured using Cronbach's Alpha as it commonly utilized with minimum value 0,700 (Mohajan, 2017). The test shown all the variables are reliable as stated on Table 1.

Table 1. Validity and Reliability

\begin{tabular}{|c|c|c|c|}
\hline Variables & Communalities & $\begin{array}{c}\text { Rotated } \\
\text { Component } \\
\text { Matrix }\end{array}$ & $\begin{array}{c}\text { Cronbach } \\
\text { Alpha }\end{array}$ \\
\hline Product Quality & & & 0,722 \\
\hline The quality Xing Fu Tang beverage is consistently high & 0,863 & 0,860 & \\
\hline Xing Fu Tang offers beverage with excellent taste & 0,734 & 0,680 & \\
\hline Perceived Value & & & 0,768 \\
\hline $\begin{array}{l}\text { Beverage served in Xing Fu Tang was a good value for the } \\
\text { price }\end{array}$ & 0,678 & 0,727 & \\
\hline Xing Fu Tang beverage was worth the money & 0,671 & 0,789 & \\
\hline $\begin{array}{l}\text { The quality and service provided by Xing Fu Tang will } \\
\text { influence my satisfaction level }\end{array}$ & 0,716 & 0,815 & \\
\hline Price Fairness & & & 0,895 \\
\hline The price of Xing Fu Tang beverage is acceptable & 0,660 & 0,771 & \\
\hline The price of Xing Fu Tang beverage is fair & 0,689 & 0,791 & \\
\hline The price of Xing Fu Tang beverage is reasonable & 0,754 & 0,825 & \\
\hline $\begin{array}{l}\text { Xing Fu Tang billing accuracy influence my satisfaction } \\
\text { level }\end{array}$ & 0,728 & 0,803 & \\
\hline $\begin{array}{l}\text { I will not be satisfied if Xing Fu Tang price is changed } \\
\text { frequently }\end{array}$ & 0,753 & 0,805 & \\
\hline EWOM & & & 0,851 \\
\hline $\begin{array}{l}\text { I will refer to Xing Fu Tang online reviews in a purchase } \\
\text { decision }\end{array}$ & 0,650 & 0,718 & \\
\hline The online review of Xing Fu Tang is understandable & 0,709 & 0,794 & \\
\hline The online review of Xing Fu Tang is credible & 0,671 & 0,741 & \\
\hline The quality of online review of Xing Fu Tang is high & 0,785 & 0,848 & \\
\hline Satisfaction & & & 0,814 \\
\hline I am satisfied with my visits to Xing Fu Tang Outlet & 0,591 & 0,639 & \\
\hline $\begin{array}{l}\text { I am pleased with the service experienced at Xing Fu Tang } \\
\text { outlet }\end{array}$ & 0,662 & 0,789 & \\
\hline $\begin{array}{l}\text { The services are offered by this outlet are always at the } \\
\text { expected level, }\end{array}$ & 0,621 & 0,693 & \\
\hline $\begin{array}{l}\text { I can get the service that Xing Fu Tang offers for me at } \\
\text { the right time, }\end{array}$ & 0,717 & 0,831 & \\
\hline Repurchase Intention & & & 0,794 \\
\hline $\begin{array}{l}\text { I have intention to return to Xing Fu Tang outlets in the } \\
\text { near future }\end{array}$ & 0,805 & 0,888 & \\
\hline $\begin{array}{l}\text { I consider Xing Fu Tang my first choice when I need } \\
\text { bubble drink again }\end{array}$ & 0,761 & 0,784 & \\
\hline $\begin{array}{l}\text { I think I will continue to come to Xing Fu Tang outlets in } \\
\text { the near future }\end{array}$ & 0,654 & 0,610 & \\
\hline
\end{tabular}


Rendika Nugraha: The Influence of ...

\section{Hypotheses Testing}

To consider hypothesis being accepted, the $p$-value must be lower than 0,05 and Critical Ratio (CR) is greater than 1,96. Out of 6 hypotheses, five hypotheses are accepted, except H5, With P-value more than 0,05 and Critical Ratio lower than 1,96, EWOM does not influence repurchase intention.

Table 2. Hypothesis Testing Result

\begin{tabular}{lccc}
\hline \multicolumn{1}{c}{ Hypothesis } & P-Value & Critical Ratio (C.R) & Result \\
\hline Product Quality Positively Influence Satisfaction (H1) & 0,001 & 14,446 & Accepted \\
Perceived Value Positively Influence Satisfaction (H2) & 0,001 & 8,165 & Accepted \\
Price Fairness Positively Influence Satisfaction (H3) & 0,015 & 2,437 & Accepted \\
EWOM Positively Influence Satisfaction (H4) & 0,028 & 2,203 & Accepted \\
EWOM Positively Influence Repurchase Intention (H5) & 0,432 & 0,785 & Rejected \\
Satisfaction Positively Influence Repurchase Intention (H6) & 0,001 & 13,211 & Accepted \\
\hline
\end{tabular}

Firstly, the result of the first hypothesis which is product quality positively influence satisfaction is accepted. This finding is supported by Han and Hyun (2017) which study focused on restaurant industry, They investigated that assessment of quality on various goods performances significantly correlated with customer satisfaction.

In addition, Konuk (2019) study on organic food restaurant support the finding that product quality is correlated with customer satisfaction. Another study in different industry by Gök et al. (2019) which focused on electrical appliance industry support quality relates to satisfaction. Quality advantages are very important to maintain customer trust in corporate market leadership (Rimawan, 2017). Many study show how big the impact of product quality in satisfying the customers. In addition, taste is one of strongest point in beverage industry, If the taste is meeting the requirements of customers, they will feel satisfied and repurchase from Xing Fu Tang.

Next, the second hypothesis which is perceived value positively influence satisfaction is accepted. This finding is similar with previous study by Konuk (2019) and Balasubramanian et al. (2018) which studies focused on food and beverage industry. In addition, study by García-Fernández et al. (2018) which study focused on fitness industry support this finding. Further stated, that perceived value is connected and positively influence with consumer satisfaction and the most important marketing concept to generate customer satisfaction and intention (Balasubramanian et al., 2018). In conclusion. if the cost spent by customers is comparable with the product and services given. they will be satisfied. In the other hand. If the customers get less than what they spend, customers might be dissatisfied.

The third hypothesis which is price fairness positively influence satisfaction is accepted. The finding is similar to the results from Ali et al. (2018) and Konuk (2018) which studies focused on food and beverage industry. Price fairness is important factor as it is significant comparator among corporates Hamenda (2018). To increase sales. many different pricing strategies can be applied. However, is not easy to select the right pricing strategies which can lead to unfavourable actions towards the seller (Abdullah et al., 2018). Many brands offering the same product. if the price is not fair or the price often to change. customers might not be satisfied. Price is important as it becomes the benchmark between Xing Fu Tang and other brands. If the price too high. customer might feel the products is not worth the product and service given and could lead to loss of sales.

Then, the fourth hypothesis which is EWOM positively influence satisfaction is accepted. The result in this study is supported by Farhat et al. (2019) which investigate that EWOM is influencing attitude of customer satisfaction. Another study in tourism industry by Setiawan et al. (2014) supports that EWOM influence customer satisfaction significantly. In addition, EWOM is important and is higher term as it is faster more convenience, wider reach, and can be done in absence of face to face human 
pressure compared to traditional WOM (Sun et al.,2006). In addition. most of Xing Fu Tang customers are millennials who close related to digital development and social media. Customer might feel the vibe of viral beverage of Xing Fu Tang and feel satisfied.

For the fifth hypothesis the result shows that EWOM is not influencing repurchase intention as the P-value result is greater than 0,050 valuing 0,432 and Critical Ratio lower than 1,960 valuing 0,785. Furthermore. EWOM does not necessarily influence repurchase intention at Xing Fu Tang. EWOM does not guarantee that repurchase intention will be occurred directly and might need mediating variable before EWOM could ended with repurchase intention. Factor such as taste might be the factor that influencing customer to repurchase the beverage from Xing Fu Tang, especially millennials who mostly more gotten in touch with digital development. Reviews only might not enough to convince them to buy again. in addition the strong point of a beverage is on the taste. If they satisfied with the taste they might repurchase again. In this study, EWOM might indirectly influence repurchase intention and satisfaction act as the mediating variable. Furthermore, below table explained the statistical result of all five hypothesis testing result.

\section{CONCLUSION}

Based on the result related to direct and indirect variable relationship. The results emphasize that Xing $\mathrm{Fu}$ Tang recommended to focus on improving product quality as it has highest critical ratio. then improving the value, strategically setting price level, building up EWOM in order to raise consumer satisfaction level and increase the repurchase intention. In the market, Xing Fu tang is required to maintain and improve their product quality through consistently keep up with standard operational procedure which will result in the taste consistency of Xing fu tang product especially for their signature drink namely brown sugar boba milk which also become the best seller for the customers. By always maintaining high standard for their product quality, it will allow Xing fu tang to comfortably stay in their price range which higher than their competitors and gain positive perceived value to always stay ahead in the competition. Product quality as the essential variable for Xing Fu Tang in accordance to the hypothesis testing result due to spread of Xing Fu Tang branch that already reach more than 30 stores nationally. This situation implies that customers are comfortable with Xing Fu Tang price range considering that not all areas have the same buying power for such beverage products. EWOM. which also positively influence customer satisfaction plays an important role to expand the reach of Xing Fu Tang products especially for new customers who are curious with Xing Fu Tang products. However, when talking about EWOM to repurchase intention. it appears that Xing Fu Tang does not necessarily gain advantage on that matters. It is because customers tendency who already land their choice when it comes to high quality boba beverages offered by Xing Fu tang makes them familiar with the unique taste.

For future studies, this study suggests adding more questions in screening questions regarding their interaction with Xing Fu Tang. Questions regarding number of times the customers bought Xing Fu Tang, their favourite beverage at Xing Fu Tang, and questions whether the customers have known regarding EWOM could lead to the respondents who are the most suitable ones. In addition, population in this study is limited only to consumer of Xing Fu Tang in Greater Jakarta. Therefore, the result may not be representative for other parts of Indonesia.

\section{REFERENCES}

Abdullah, D., Hamir. N., Nor. N. M., Jayaraman. K., \& Rostum, A. M. M. (2018). Food Quality, Service Quality, Price Fairness and Restaurant Re-Patronage Intention: The Mediating Role Of Customer 
Rendika Nugraha: The Influence of ...

Satisfaction. International Journal Of Academic Research In Business And Social Sciences, 8(17), 211-226. https://doi.org/10.6007/ijarbss/v8-i17/5226

Ali, L., Yee, W., Imm, N., \& Akhtar. M. (2018). Price Fairness, Guest Emotions, Satisfaction, and Behavioral Intentions In Peer To Peer Accommodation Sector. Journal Of Global Business Insights, 3(2), 41-51. https://doi.org/10.5038/2640-6489.3.2.1035

Anggraeni, A., \& Luthfi, A. (2018). The Impact Of Electronic Word-Of-Mouth On Brand Image. Attitude Toward Product. Perceived Quality And Visit Intention: An Empirical Study Of The Food And Beverage Industry In Jakarta. 4th Gadjah Mada International Conference On Economic And Business 2016, 4(1), 548-561.

Araci, U. E., Bulut, Z. A., \& Kocak. N. (2017). The Relation Among Experiential Marketing. Customer Satisfaction. And Behavioral Intention: A Study On Food And Beverage Businesses (Paper Presentation). 23th International Scientific Conference On Economic And Social Development. 361-371.

Astutik, Y. (2019, April 30). Penjualan Bubble Tea Lewat Grabfood Naik 31 Kali Lipat. CNBC Indonesia. Https://Www.Cnbcindonesia.Com/Tech/20190430132514-37-69686/Penjualan-Bubble-TeaLewat-Grabfood-Naik-31-Kali-Lipat

Balasubramanian, K., Mun, F. W., \& Ramalingam, V. (2018). The Bubble Drink Industry In Malaysia: An Empirical Assesment Of Repurchase Intention. Asia-Pacific Journal Of Innovation In Hospitality and Tourism, 7(2), 103-119.

Chan, L. L., \& Idris. N. (2017). Validity And Reliability Of The Instrument Using Exploratory Factor Analysis And Cronbachâ ${ }^{\mathrm{T}} \mathrm{S}$ Alpha. International Journal Of Academic Research In Business And Social Sciences. 7(10). 400-410. https://doi.org/10.6007/ijarbss/v7-i10/3387

Dandotiya. R., Aggarwal. P., \& Gopal. R. (2020). Impact Of Food And Beverage Quality On Passenger Satisfaction In Indian Railways. International Journal Of Customer Relationship Marketing And Management, 11(2), 37-52. https://doi.org/10.4018/ijcrmm.2020040103

Farhat. K., Aslam. W., \& Arif. I. (2019). Role of Electronic Word of Mouth on Purchase Intention. International Journal of Business Information Systems, 30(4), 411-426. https://doi.org/10.1504/ljbis.2019.10020633

García-Fernández. J., Gálvez-Ruíz. P., Fernández-Gavira. J., Vélez-Colón. L., Pitts. B., \& Bernal-García. A. (2018). The Effects of Service Convenience and Perceived Quality on Perceived Value, Satisfaction and Loyalty in Low-Cost Fitness Centers. Sport Management Review, 21(3), 250-262. https://doi.org/10.1016/J.Smr.2017.07.003

Gök, O., Ersoy. P., \& Börühan. G. (2019). The Effect of User Manual Quality on Customer Satisfaction: The Mediating Effect of Perceived Product Quality. Journal Of Product And Brand Management, 28(4), 475-488. https://doi.org/10.1108/JPBM-10-2018-2054

Grab. (2019). Demam Bubble Tea Di Grabfood!. Grab. https://www.grab.com/id/press/techproduct/demam-bubble-tea-di-grabfood/

Hamenda, A. (2018). An Integrated Model of Service Quality, Price Fairness, Ethical Practice and Customer Perceived Values for Customer Satisfaction of Sharing Economy Platform. International Journal Of Business And Society, 19(3), 709-724.

Han, H., \& Hyun, S. S. (2017). Impact of Hotel-Restaurant Image and Quality of Physical-Environment. Service and Food on Satisfaction and Intention. International Journal Of Hospitality Management, 63, 82-92. https://doi.org/10.1016/J.ljhm.2017.03.006 
Ismail, I. L. (2020. January 23). Fenomena Tren Boba Di Indonesia. Apa Dampaknya? - Radio RDK. Retrieved May 17. 2020. From Http://Rdk.Fidkom.Uinjkt.Ac.Id/Index.Php/2020/01/23/FenomenaTren-Boba-Di-Indonesia-Apa-Dampaknya/

Ismoyo, N. B., Hadiwidjojo, D., Rahman, F., \& Mintarti, R. (2017). Service Quality Perception's Effect On Customer Satisfaction And Repurchase Intention. European Business \& Management, 3(3), 37-46. https://doi.org/10.11648/J.Ebm.20170303.11

Karen, Z., \& Lau, C. (2019, January 1). Hong Kong Distributor Of Popular Taiwanese Bubble Tea Brand Xing Fu Tang Shocks Customers By Suddenly Shutting Store Amid Bitter Court Battle With Founding Firm. South China Morning Post. https://Www.Scmp.Com/News/HongKong/Society/Article/2180310/Hong-Kong-Distributor-Popular-Taiwanese-Bubble-Brand-Xing-Fu

Konuk, F. A. (2018). Price Fairness. Satisfaction. And Trust As Antecedents Of Purchase Intentions Towards Organic Food. Journal of Consumer Behaviour, 17(2), 141-148. https://doi.org/10.1002/cb.1697

Konuk, F. A. (2019). The Influence Of Perceived Food Quality. Price Fairness. Perceived Value And Satisfaction On Customers' Revisit And Word-Of-Mouth Intentions Towards Organic Food Restaurants. Journal of Retailing And Consumer Services, 50, 103-110. https://doi.org/10.1016/j.jretconser.2019.05.005

Kumparan. (2019, July 28). Ini Dia Brown Sugar Boba Milk Dari Xing Fu Tang Yang Bikin Ngantri. Kumparan Food. https://kumparan.com/kumparanfood/ini-dia-brown-sugar-boba-milk-dari-xingfu-tang-yang-bikin-ngantri-1rY8gVrOGv1

Kuo, Y. F., Hu. T. L., \& Yang. S. C. (2013). Effects Of Inertia And Satisfaction In Female Online Shoppers On Repeat Purchase Intention:The Moderating Roles Of Word Of Mouth And Alternative Attraction. Managing Service Quality: An International Journal, 23(3, 168-187. https://doi.org/10.1108/09604521311312219

Liang, L. J., Choi. H. C., \& Joppe, M. (2017). Understanding Repurchase Intention Of Airbnb Consumers: Perceived Authenticity. Electronic Word-Of-Mouth. And Price Sensitivity. Journal Of Travel And Tourism Marketing, 35(1), 73-89. https://doi.org/10.1080/10548408.2016.1224750

Lidyana. V. (2019a, Oktober 27). Boba Yang Jadi Primadona Milenial Hingga Generasi Z. Finance Detik. https://finance.detik.com/berita-ekonomi-bisnis/d-4761337/boba-yang-jadi-primadona-milenialhingga-generasi-z

Lidyana. V. (2019b, Oktober 27). Manisnya Bisnis Boba. 3 Ribu Gelas Ludes/Hari. Finance Detik. https://finance.detik.com/berita-ekonomi-bisnis/d-4761449/manisnya-bisnis-boba-3-ribu-gelasludeshari

Mao, Z., \& Lyu, J. (2017). Why Travelers Use Airbnb Again?: An Integrative Approach To Understanding Travelers' Repurchase Intention. International Journal Of Contemporary Hospitality Management. 29(9), 2464-2482. https://doi.org/10.1108/ijchm-08-2016-0439

Matute, J., Polo-Redondo. Y., \& Utrillas. A. (2016). The Influence Of EWOM Characteristics On Online Repurchase Intention: Mediating Roles Of Trust And Perceived Usefulness. Online Information Review. 40(7). 1090-1110. https://doi.org/10.1108/oir-11-2015-0373

Mohajan, H. K. (2017). Two Criteria For Good Measurements In Research: Validity And Reliability. Annals Of Spiru Haret University, 8(17)(4), 59-82. https://doi.org/https://doi.org/10.26458/1746 
Mustinda. L. (2019). Xing Fu Tang: Antre 2 Jam Untuk Cicipi Brown Sugar Boba Milk.Retrieved From Https://Food.Detik.Com/Resto-Dan-Kafe/D-4592367/Xing-Fu-Tang-Antre-2-Jam-Untuk-CicipiBrown-Sugar-Boba-Milk

Nazri, M., Raji. A., \& Zainal. A. (2016). The Effect Of Customer Perceived Value On Customer Satisfaction: A Case Study Of Malay Upscale Restaurants. Geografia - Malaysian Journal Of Society And Space, 12(3), 58-68.

Rakyat Merdeka News. (2019, August 10). Xing Fu Tang Gerai Minuman Yang Terlebih Dahulu Populer Di Taiwan. Rakyat Merdeka News. https://rakyatmerdekanews.com/tag/xing-fu-tang-geraiminuman-yang-terlebih-dahulu-populer-di-taiwan/

Rimawan, E., Mustofa. A., \& Mulyanto, A. D. (2017). The Influence Of Product Quality. Service Quality And Trust On Customer Satisfaction And Its Impact On Customer Loyalty (Case Study PT ABC Tbk). International Journal of Scientific \& Engineering Research, 8(7), 2330-2336. https://doi.org/10.13140/rg.2.2.29557.93925

Ryu, K., \& Lee, J. S. (2016). Examination Of Restaurant Quality. Relationship Benefits. And Customer Reciprocity From The Perspective Of Relationship Marketing Investments. Journal Of Hospitality and Tourism Research, 41(1), 66-92. https://doi.org/10.1177/1096348013515919

Setiawan, P. Y., Troena, E. A., Armanu, \& Noermijati. (2014). The Effect Of E-WOM On Destination Image. Satisfaction And Loyalty. International Journal Of Business And Management Invention ISSN (Online, 3(1), 2319-8028.

Sun, T., Youn, S., Wu. G., \& Kuntaraporn, M. (2006). Online Word-Of-Mouth (Or Mouse): An Exploration Of Its Antecedents And Consequences. Journal Of Computer-Mediated Communication, 11(4), 1104-1127. https://doi.org/10.1111/j.1083-6101.2006.00310.X 